\title{
Incidence and etiologic factors responsible for anovulation in infertility cases
}

\section{Rajeshwari Singangutti*}

Department of Obstetrics and Gynecology, Chalmeda Anand Rao Institute of Medical Sciences, Karimnagar, Telangana, India

Received: 07 February 2018

Accepted: 07 March 2018

*Correspondence:

Dr. Rajeshwari Singangutti,

E-mail: rajeshwaris1983@gmail.com

Copyright: () the author(s), publisher and licensee Medip Academy. This is an open-access article distributed under the terms of the Creative Commons Attribution Non-Commercial License, which permits unrestricted non-commercial use, distribution, and reproduction in any medium, provided the original work is properly cited.

\section{ABSTRACT}

Background: Chronic anovulation is a common cause of infertility. Anovulation leads to a long-term problem such as hyperandrogenism. Anovulation usually associated with amenorrhoea about $20 \%$ and oligomenorrhoea of women with ovulatory dysfunction. Present study was designed to assess the incidence and etiological factors responsible for anovulation in infertility cases.

Methods: Study comprised of one hundred patients attending the outdoor clinic of the department for infertility either primary or secondary with regular and irregular menstrual cycles and patients of secondary amenorrhoea.

Results: Among the total cases Polymenorrhoea was seen in $10 \%$ of cases, oligomenorrhea in $14 \%$ cases, secondary amenorrhoea in $3 \%$ and $73 \%$ cases had normal menstrual cycle. cervical mucus viscosity in ovulatory group to be low in $84.6 \%$ cases, moderate in $8.5 \%$ cases and high in $38 \%$ cases. In anovulatory cycles findings were reversed with viscosity at 14 th day it was moderate in $27.27 \%$ and higher in $54.54 \%$ cases.

Conclusions: Cervical mucus is a good indicator of the cyclical changes in ovarian hormonal as no false positive results were found. Endometrial biopsy is the mainstay in infertility studios as it provides information regarding the ovulating status.

Keywords: Amenorrhoea, Anovulation, Endometrial biopsy, Infertility, Oligomenorrhoea

\section{INTRODUCTION}

Anovulation is the major cause of infertility which accounts for $30 \%$ of infertility and often present with Oligomenorrhoea and amenorrhoea. ${ }^{1}$ Anovulatory condition can be consider if no indices of ovulation for 23 months to six months or longer period of secondary amenorrhoea. $^{2}$ Infertility is a major health hazard in present society among worldwide. In developed countries prevalence of infertility is $3.5-16.75 \%$, where as in developing countries prevalence is $6.9-9.3 \% .^{3,4}$ Treatment modalities are simple and effective for anovulation however, not all causes of anovulation are amenable to treatment by ovulation index. ${ }^{5}$ Ovulation can be detected by different parameters such as changes in cervical mucus, properties and its constituents, basal body temperature, serial vaginal smears, endometrial biopsy, essay of serum progesterone or urinary pregnendiol and other hormonal measurements. Daily vaginal smears, basal body temperature charting and cervical mucus requires careful monitoring of the patients over a long period of time. ${ }^{6}$

One can arrive at a definitive conclusion by the estimation of a rapid LH assay, but from a practical point of view these are expensive and not available in most in expensive procedures for judging ovulation need to be evaluated. With the above facts the present study was 
undertaken to assess the incidence and etiological factors responsible for anovulation in infertility cases.

\section{METHODS}

The present study was carried out in the Department of Obstetrics and Gynaecology in association with Department of Pathology, Chalmeda Anand Rao Institute of Medical Sciences, Karimnagar over a period April 2016 to September 2017 for the assessment of anovulation in female infertility. The study comprised of one hundred patients attending the outdoor clinic of the department for infertility either primary or secondary with regular and irregular menstrual cycles and patients of secondary amenorrhoea.

A written informed consent was obtained from the patients. A detailed history of patients by general, systemic and local examination was taken. A complete haemogram, hormonal assay was conducted, and endometrial biopsy was collected for histopathological examination.

Samples of cervical mucus were collected during selection period of menstrual cycle i.e. in post ovulatory period to see the ferning is appearing or not appearing. Cervical mucus was studied for to assess the viscosity, spinbility, fern test.

Hormonal assay for LH, FSH, Serum prolactin and thyroid hormones was performed to detect the disorders which may leads to anovulation and infertility.

\section{RESULTS}

A total one hundred infertility and secondary amenorrhoea patients were considered to assess the incidence of anovulation in infertility women and etiological factors responsible for anovulation. Majority (76\%) number of cases in this study complained primary infertility and $18 \%$ cases complained secondary sterility (Table 1).

Table 1: Distribution of cases according to chief complaints.

\begin{tabular}{|lll|}
\hline Chief complaints & No. of cases & Percentage \\
\hline Primary infertility & 76 & 76 \\
\hline Secondary sterility & 18 & 18 \\
\hline Secondary amenorrhoea & 6 & 6 \\
\hline
\end{tabular}

Maximum number of cases belongs to 21-25 years age group. Based on economic status, 64\% were belongs to middle income zone and rest were in low economy group. Among the patients 54\% were residing in urban areas and $46 \%$ in rural areas.

Among the total cases Polymenorrhoea was seen in $10 \%$ of cases, oligomenorrhea in $14 \%$ cases, secondary amenorrhoea in $3 \%$ and $73 \%$ cases had normal menstrual cycle. In the present study, $78 \%$ of cases were suffered with sterility for 1-5 years and $3 \%$ cases with suffered with 16-20 years duration.

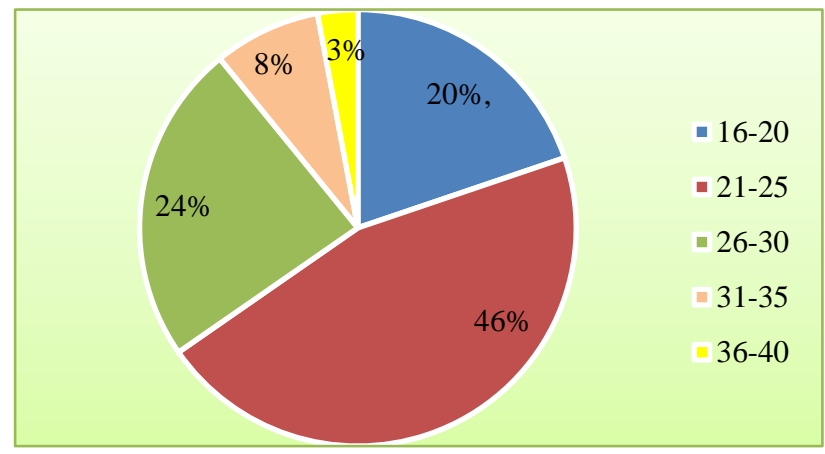

Figure 1: Distribution of cases according to their age.

Among 73 cases having normal menstrual cycle, 52 $(71.2 \%)$ suffered from primary infertility while remaining $21(28.8 \%)$ suffered from secondary infertility. All the polymenorrhoea cases complained primary infertility (Table 2).

Table 2: Distribution of cases according to menstrual pattern and sterility.

\begin{tabular}{|lllll|}
\hline Menstrual pattern & \multicolumn{2}{l}{$\begin{array}{l}\text { Primary } \\
\text { sterility }\end{array}$} & \multicolumn{2}{l|}{$\begin{array}{l}\text { Secondary } \\
\text { sterility }\end{array}$} \\
\hline & No. & $\%$ & No. & $\%$ \\
\hline Polymenorrhoea $(\mathrm{n}=10)$ & 10 & 100 & - & - \\
\hline Normal $(\mathrm{n}=73)$ & 52 & 71.2 & 21 & 28.8 \\
\hline $\begin{array}{l}\text { Oligomenorrhea }(\mathrm{n}=14) \\
\text { Secondary amenorrhoea } \\
(\mathrm{n}=3)\end{array}$ & 10 & 71.5 & 4 & 28.5 \\
\hline
\end{tabular}

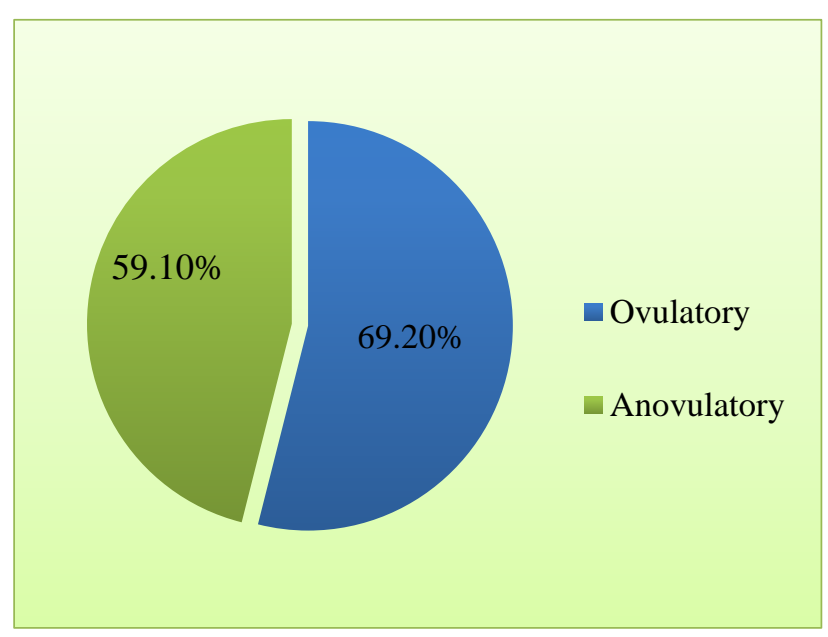

Figure 2: Distribution of cases according to premenstrual dysmenorrhoea.

Hypoplastic uterus was found in $3 \%$ cases of polymenorrhoea, $13.6 \%$ in normal menstrual cases, $35.8 \%$ cases in oligomenorrhoea and $33.3 \%$ in secondary amenorrhoea. Both ovaries were palpable in $2.7 \%$ normal 
menstrual cycle cases. Cystic ovary was observed in one normal menstrual cycle case (Table 3). Premenstrual dysmenorrhoea was present in $69.2 \%$ cases of ovulatory and $59.1 \%$ cases of anovulatory patients (Figure 2).

Table 3: Distribution of cases according to per vaginal (P/V) examination.

\begin{tabular}{|c|c|c|c|c|c|c|c|c|c|c|c|c|}
\hline \multirow{3}{*}{ Menstrual pattern } & \multirow{2}{*}{\multicolumn{2}{|c|}{$\begin{array}{l}\text { Нуро } \\
\text { uterus }\end{array}$}} & \multirow{2}{*}{\multicolumn{2}{|c|}{$\begin{array}{l}\text { Normal } \\
\text { uterus }\end{array}$}} & \multicolumn{4}{|c|}{ Palpable ovary } & \multicolumn{4}{|c|}{ Cystic ovary } \\
\hline & & & & & \multicolumn{2}{|c|}{ Single } & \multicolumn{2}{|c|}{ Both } & \multicolumn{2}{|c|}{ Single } & \multicolumn{2}{|c|}{ Both } \\
\hline & No. & $(\%)$ & No. & $(\%)$ & No. & $(\%)$ & No. & $(\%)$ & No. & $(\%)$ & No. & $(\%)$ \\
\hline Normal $(n=73)$ & 10 & 13.6 & 54 & 73.9 & 6 & 8.2 & 2 & 2.7 & 1 & 1.3 & - & - \\
\hline Polymenorrhoea $(n=10)$ & 3 & 3 & 7 & 7 & - & - & - & - & - & - & - & - \\
\hline Oligomenorrhoea $(n=14)$ & 5 & 35.8 & 8 & 57.1 & 1 & 7.1 & - & - & - & - & - & - \\
\hline Secondary amenorrhoea $(n=3)$ & 1 & 33.3 & 1 & 33.3 & 1 & 33.3 & - & - & - & - & - & - \\
\hline
\end{tabular}

Breast tenderness was present in $26.9 \%$ cases of ovulatory as against 9.09 cases of anovulatory patients. Abdominal fullness was experienced by $23.07 \%$ cases of ovulatory and $4.5 \%$ anovulatory cases (Table 4 ).

Table 4: Distribution of cases according to premenstrual molimina.

\begin{tabular}{|lllllll|}
\hline $\begin{array}{l}\text { Ovulatory } \\
\text { pattern }\end{array}$ & \multicolumn{2}{l}{$\begin{array}{l}\text { Breast } \\
\text { tenderness }\end{array}$} & \multicolumn{2}{l}{$\begin{array}{l}\text { Abdominal } \\
\text { fullness }\end{array}$} & \multicolumn{2}{l|}{ Headache } \\
\hline $\begin{array}{l}\text { Ovulatory (n } \\
\text { No }\end{array}$ & 21 & 26.9 & 18 & 23.07 & 2 & 2.56 \\
\hline $\begin{array}{l}\text { Anovulatory } \\
(\mathrm{n}=22)\end{array}$ & 2 & 9.09 & 1 & 4.5 & - & - \\
\hline
\end{tabular}

Overall incidence of ovulation as seen by endometrial biopsy in polymenorrhoea showed $70 \%$ in ovulatory cases and $30 \%$ in anovulatory cases. In normal menstrual cases, $71.24 \%$ in ovulatory cases and $28.76 \%$ in anovulatory cases (Table 5).

Table 5: Distribution of cases according to menstrual pattern and ovulation as seen by endometrial biopsy.

\begin{tabular}{|lllll|}
\hline \multirow{2}{*}{ Menstrual pattern } & \multicolumn{2}{c}{ Ovulatory } & \multicolumn{2}{c|}{ Anovulatory } \\
\hline Normal $(\mathrm{n}=73)$ & No. & \% & No. & $\%$ \\
\hline Polymenorrhoea $(\mathrm{n}=10)$ & 7 & 71.24 & 21 & 28.76 \\
\hline Oligomenorrhea $(\mathrm{n}=14)$ & 9 & 64.2 & 5 & 30 \\
\hline $\begin{array}{l}\text { Secondary amenorrhoea } \\
(\mathrm{n}=3)\end{array}$ & 1 & 33.3 & 2 & 666 \\
\hline
\end{tabular}

Table 6: Distribution of cases according to cervical mucus viscosity in relation to anovulation.

\begin{tabular}{|c|c|c|c|c|c|c|}
\hline \multirow{3}{*}{$\begin{array}{l}\text { Ovulatory } \\
\text { pattern }\end{array}$} & \multicolumn{6}{|c|}{ Viscosity } \\
\hline & \multicolumn{2}{|c|}{ Mild } & \multicolumn{2}{|c|}{ Moderate } & \multicolumn{2}{|c|}{ High } \\
\hline & No. & $\%$ & No. & $\%$ & No. & $\%$ \\
\hline $\begin{array}{l}\text { Ovulatory } \\
\text { premenstrual ( } 78\end{array}$ & 66 & 84.6 & 9 & 11.5 & 3 & 3.8 \\
\hline $\begin{array}{l}\text { Anovulatory } \\
\text { premenstrual } \\
\text { (22) }\end{array}$ & 4 & 18.18 & 6 & 27.27 & 12 & 54.54 \\
\hline
\end{tabular}

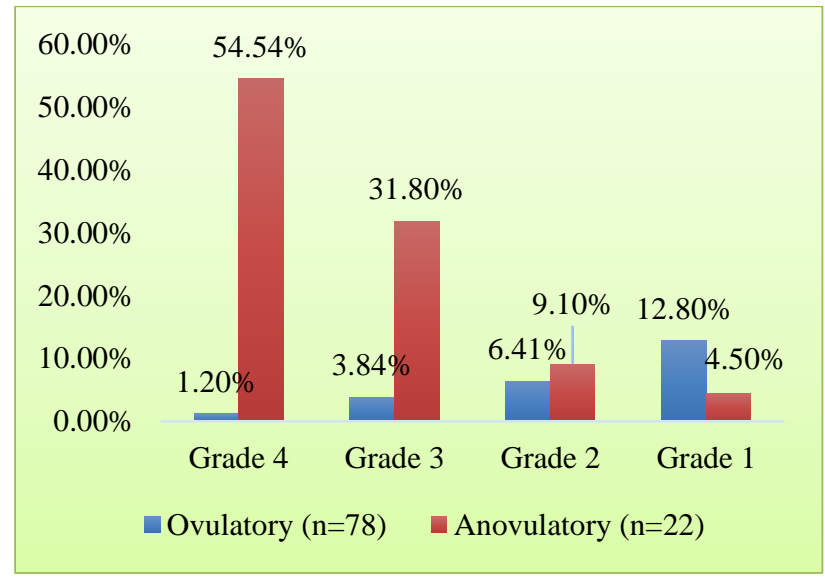

Figure 3: Distribution of cases according to ferning property of cervical mucus in relation to ovulation pattern.

Viscosity in premenstrual period was mild in $84.6 \%$, moderate in $11.5 \%$ and high in $3.8 \%$ of ovulatory premenstrual cases. Whereas in anovulatory premenstrual cases viscosity was mild in $18.18 \%$, moderate in $27.27 \%$ and high in $54.54 \%$ (Table 6). Ferning was high graded (Grade 4 and 3) in anovulatory infertility cases and in ovulatory infertility it was gradually high in grade 1 and 2 (Figure 3).

\section{DISCUSSION}

Anovulation is the major cause of infertility which accounts for $30 \%$ of infertility and often present with Oligomenorrhoea and amenorrhoea. ${ }^{7}$ The present study was performed to assess the incidence and etiological factors responsible for anovulation. In this study $76 \%$ cases were belonging to primary infertility and $18 \%$ complained secondary infertility. Majority cases were between age group 21-25 years. 64\% of cases were in middle economic status and rest in low economy zone. Among the patients $54 \%$ were residing in urban areas and $46 \%$ in rural areas.

In the present study complete cases with polymenorrhoea and $71.5 \%$ with oligomenorrhoea had primary infertility. 
$71.2 \%$ cases with normal menstrual cycles had primary infertility this may be due to failure to anovulate or by other factors. Premenstrual dysmenorrhoea was seen in $69.20 \%$ cases of ovulatory cycles and $40.09 \%$ in anovulatory cycles which are correlating with the findings of Lamb et al, who found it in up to $75 \%$ of cases. Molimina symptoms such as breast tenderness, headache, oedema and dysmenorrhoea are generally believed to occur in ovulatory cycles. ${ }^{8,9}$

In the present study cervical mucus viscosity in ovulatory group to be low in $84.6 \%$ cases, moderate in $8.5 \%$ cases and high in $38 \%$ cases. In anovulatory cycles findings were reversed with viscosity at $14^{\text {th }}$ day it was moderate in $27.27 \% \%$ and higher in $54.54 \%$ cases. Changes in cervical mucus is quite reliable with the findings of Gates $\mathrm{W}$ et al. ${ }^{10} \mathrm{In}$ anovulatory group, ferning was +1 to +4 in $4.50 \%, 9.10 \%, 31.80 \%$ and $54.54 \%$ respectively. This indicates the continuous unopposed action of oestrogen on cervical mucus due to persistence of Graafian follicle and failure of ovulation to occur.

In view of endometrial biopsy, anovulation was found in $30 \%$ cases of polymenorrhoea $(n=10), 35.7 \%$ cases of oligomenorrhoea $(n=14)$ and $66.6 \%$ of secondary amenorrhoea $(n=3)$ with lowest incidence in cases with normal menstrual cycle $(\mathrm{n}=73)(28.76 \%)$. Endometrial biopsy is the best single test for ovulation detection. ${ }^{11}$

The ultrasonography findings showed that detection of ovulation by ultrasonography in comparison with endometrial biopsy is almost the same. Ultrasonographic findings showed that ovulation was detected in $92.3 \% \%$ cases with secretary endometrium and only $7.69 \%$ cases has no ovulation with secretary endometrium.

\section{CONCLUSION}

Premenstrual molimina are associated with more commonly but not always with ovulatory cycles. Cervical mucus is a good indicator of the cyclical changes in ovarian hormonal as no false positive results were found. Endometrial biopsy is the mainstay in infertility studios as it provides information regarding the ovulating status. Serial ultrasonography for detection of ovulation is the confirmatory investigation, but it was very expensive for our poor population and result with endometrial biopsy and ultrasonography were almost same.

Funding: No funding sources Conflict of interest: None declared
Ethical approval: The study was approved by the Institutional Ethics Committee

\section{REFERENCES}

1. Saha TC. Aetiological factors of sterility in India. Indian J Obstet Gynec. 1961;II:225.

2. Mascarenhas MN, Flaxman SR, Boerma $\mathrm{T}$, Vanderpoel S, Stevens GA. National, regional, and global trends in infertility prevalence since 1990: a systematic analysis of 277 health surveys. Plos Med. 2012;9(12):e1001356.

3. Scarneciu I, Lupu S, Scarneciu C. Smoking as a risk factor for the development of erectile dysfunction and infertility in men; evaluation depending on the anxiety levels of these patients. Soc Behav Sci. 2014;127(1):437-42.

4. Rahim R, Majid S. Aetiological factors of infertility. JPMI. 2004;18:166-71.

5. Palihawadana TS, Wijesinghe PS, Seneviratne HR. Aetiology of infertility among females seeking treatment at a tertiary care hospital in Sri Lanka. Ceylon Med J. 2012;57(2):79-83.

6. Mayyar DM, Boyers SP, Marshall JR, Abraham GE. Regular menstrual cycles and premenstrual molimina as indicators of ovulation. Obstet Gynecol. 1979;53:441.

7. National Institute for Health and Clinical Excellence. Fertility: assessment and treatment for people with fertility problems. National Collaborating Centre for Women's and Children's Health. London: RCOG Press; 2004.

8. Israel R, Mishell Jr R, Stone SC, Thorneycroft IH, Moyer DL. Single luteal phase serum progesterone assay as an indicator of ovulation. Am J Obset Gynecol. 1972;112:1043.

9. Luciano A, Lanzone A, Goverde A. Management of female infertility from hormonal causes. Int $\mathbf{J}$ Gynecol Obstet. 2013;123:S9-S17.

10. Cates W, Farley T, Rowe P. Worldwide patterns of infertility: is Africa different. Lancet. 1985;2:596-8.

11. Dhont N, Luchters S, Muvunyi C. The risk factor profile of women with secondary infertility: an unmatched case-control study in Kigali, Rwanda. BMC Womens Health. 2011;11:32.

Cite this article as: Singangutti R. Incidence and etiologic factors responsible for anovulation in infertility cases. Int J Reprod Contracept Obstet Gynecol 2018;7:1567-70. 